\title{
A Preliminary Study on the Changes in the Italian Automotive Supply Chain for the Introduction of Electric Vehicles
}

\author{
Matteo Rossini ${ }^{1}$ (D), Filippo Emanuele Ciarapica ${ }^{2}$ iD, Dominik Tobias Matt ${ }^{1}$ (D), \\ Pasquale Russo Spena ${ }^{1}$ iD \\ ${ }^{1}$ Faculty of Science and Technology, Free University of Bozen-Bolzano (Italy) \\ ${ }^{2}$ Department of Industrial Engineering and Mathematical Science, Università Politecnica delle Marche (Italy) \\ matteo.rossini@unibr.it,.fciarapica@univpm.it,_dominik.matt@unibr.it, pasquale.russospena@,unibr.it
}

Received: May 2015

Accepted: April 2016

\section{Abstract:}

Purpose: A survey has been carried out among Italian car makers, suppliers, and customers to identify the potential changes that the traditional Italian automotive supply chain would need for the introduction of electric vehicles. In addition, this study investigates the degree of importance that enterprises attribute to the electric vehicle market and their perceptions about the development of this market, also evaluating which types of electric vehicles and body styles are receiving the most relevant investment.

Design/methodology/approach: An empirical investigation has been carried out to examine the above-mentioned aspects. Data have been collected through an on-line survey and analysed by a descriptive statistical analysis, confirmatory factors analysis, and cluster analyses.

Findings: Market penetration of electric vehicles is mainly influenced by technological choices of car makers and battery manufacturers and by the ability to organize and manage the integrated actions of stakeholders, also including component suppliers, and manufacturers of vehicle management systems. Stakeholders have to exploit economies of scale, to make use and expand long-time competencies in electric engineering with automotive know-how, and to build up cooperation with experts in the new value chain to facilitate the required transfer of know-how. Alliances and joint ventures can provide manufacturers access to the know-how, technology, and 
production capacity of battery suppliers. Outsourcing, especially as regards research and development, will occur even more frequently in the near future. An agile supply chain should be adopted to manage a fluctuating market demand.

Originality/value: This preliminary study contributes to provide an outlook of some of the most important changes that traditional Italian automotive supply chain would need to promote the introduction of electric vehicles and their critical components with an emphasis on production aspects.

Keywords: electromobility, supply chain, survey, business strategy, cluster analysis, confirmatory factor analysis

\section{Introduction}

According to Fine (2000), the term supply chain design is defined as "choosing what capabilities along the value chain to invest in and develop internally, and which to allocate for development by suppliers". Through the process of supply chain design, companies define strategies to manage their supply chains and configurations by defining operational processes and the members of the supply chain responsible for performing these processes themselves. The term new product development process means "the set of activities beginning with the perception of a market opportunity and ending in the production, sale and delivery of a product" (Ulrich \& Eppinger, 2000). It is the primary means of generating innovation in companies and allows them to adapt their offerings based on evolutions in technology and consumer preferences (Liu, Chen \& Niu, 2015). From these considerations, the importance of an effective management of the new product development process is crucial; its absence might potentially represent a business risk. New product development and supply chain design are strongly interconnected, and their coordinated management is essential for the successful introduction of new products to the market (Caniato \& Größler, 2015). In this regard, companies must choose both the strategy and the configuration of the supply chain that are most suitable to the characteristics of the new product.

Traditional vehicles are typically based on steel bodies and fitted with internal combustion engines. These vehicles are designed and manufactured in a production system characterised by modular design and manufacturing strategies for the core technologies fitted in the cars (Persson, 2006; Jacobs, Vickey \& Droge, 2007; Pandremenos, Paralikas, Salonitis \& Chryssolouris, 2009). The modular design and manufacturing system enables vehicle manufacturers to increase scale and cut costs, but it also rises sunk costs in production equipment at the vehicle assembly plants. These costs may create high entry barriers 
to technologies that are not easily adaptable to the mass-production paradigm of the conventional automotive industry (Andrews, Nieuwenhuis \& Ewing, 2006; Bevilacqua, Ciarapica \& Paciarotti, 2012).

These aspects are of utmost importance for automotive companies that are moving, or that have the intention of moving, towards the production of electric vehicles (EVs). The decisions necessary to implement EVs are even more crucial for companies that plan to integrate EVs into their existing production lines of traditional vehicles. In fact, sustainable passenger mobility and, hence, alternative powertrain concepts (e.g., full electric or hybrid) will see increasing demand over the next 20 years (Ciarapica, Matt, Luccarelli, Rossini \& Russo Spena, 2012).

The integration of alternative powertrain concepts into passenger cars will require completely new components and competencies. In this regard, some small- and medium-sized enterprises (SMEs), which are currently not present in the traditional automotive supply chain, will become notably involved in the EV supply chain by providing new automotive components and facilities. EV supply chain differs considerably from that of a conventional vehicle; especially concerning the linkages to other industrial sectors such as energy suppliers (Hensley, Knupfer \& Pinner, 2009; Pannkoke \& Ernst, 2011) and service providers (Enrietti \& Patrucco, 2011). Luccarelli, Matt and Russo Spena (2014) argued that the full potential of the alternative drivetrains is unexploited unless the complete vehicle system is re-invented. Moreover, many components that are currently used in internal combustion engine vehicles will be no longer necessary in a full EV (e.g., exhaust, intake, $\mathrm{O}_{2}$ sensor, and EGR). A fully developed EV supply chain will be achieved only if companies can succeed in synthesising automotive and EV competencies from industry, research and development, and educational resources.

This preliminary study contributes to provide an outlook of some of the most important changes that traditional Italian automotive supply chain would need to promote the introduction of electric vehicles and their critical components with an emphasis on the production aspects. An empirical investigation was carried out to examine these aspects and to probe these enterprises' perceptions about the development of the electric-vehicle market focusing on hybrid, plug-in hybrid, and full electric vehicles. The data were collected through an on-line survey and analysed by a descriptive statistical analysis, confirmatory factor analysis and cluster analyses. An additional aim of the survey was to evaluate which type of electric vehicle and body style enterprises are mainly investing on and the degree of importance that they attribute to the electric vehicle market.

The paper is organised as follows: i) section 2 describes the theoretical framework at the basis of this study; ii) section 3 explains the methodology used, including the development of the questionnaire, the identification of companies to set the statistical sample and the statistical analyses performed; iii) section 4 provides the results of the study; iv) section 5 summarises and discusses the outcomes from this study; v) section 6 lists the conclusions. 


\section{Theoretical Framework and Research Hypothesis}

\subsection{Supply Chain and New Products}

It is crucial for companies to continuously introduce innovative products and make variations to existing products to remain competitive in the market. However, the ability to design new products in response to technological developments and market trends is not sufficient to ensure the survival of a company. In fact, today's competitive market has led to an increase in demand heterogeneity and, in turn, to a proliferation of products with reduced life cycles, which creates a risk of stock obsolescence and validates the importance of time-to-market (Fixson, 2005; Van Hoek \& Chapman, 2006; Duffy, 2010; Cao \& Folan, 2012; Jin \& Tian, 2015). In addition, there is a growing trend in outsourcing of production and design activities (McCarthy, Silvestre \& Ketzmann, 2013) together with an increase in the strategic nature of purchases, which can represent as much as $60-80 \%$ of the sales value (Kraljic, 1983; Keough, 1993). In fact, a distinct feature of the automotive production system is the high amount of car components produced by external suppliers (Christensen, 2011). Nowadays, around 75\% of vehicle production (IHS Global Insight, 2009) and about 50\% of automotive R\&D are carried out by external suppliers (Christensen, 2011). For these reasons, product design, production processes design, and decisions relating to the supply chain must be coordinated instead of being perceived as separate sets of decisions and activities (Rungtusanatham \& Forza, 2005). This leads to an extension of the conventional Concurrent Engineering concept into so-called 3-Dimensional Concurrent Engineering (3-DCE) (Fixson, 2005). According to Fine (1998), 3-DCE can be defined as the simultaneous and coordinated design of products, manufacturing processes, and supply chains. Fine (2000) also suggests that the necessity of integrating these three processes becomes almost an obligation once the strategic importance of the supply chain is recognised. The literature (Lee \& Sasser, 1995; Sharifi, Ismail \& Reid, 2006; Van Hoek \& Chapman, 2006, 2007; Khan \& Creazza, 2009; Nooria \& Georgescua, 2010; Yadav, Mishrab, Kumarc \& Tiwarid, 2010) has identified the need to match the characteristics of a product with those of the supply chain to control costs and maximise the service performance of the supply chain. These goals can be achieved not only by choosing the proper strategy and configuration of the supply chain, but also by trying to anticipate possible constraints during the product design stage (e.g., delays in the launch of new products due to non-readiness of the supply chain). As noted by Van Hoek and Chapman (2006), the old literature proposed that it was only necessary to pre-inform the actors at the end of the supply chain to ensure the availability of components and supplies for the production and product availability during a market launch (Novak \& Eppinger, 2001). Recent studies (Lamothe, Hadj-Hamou \& Aldanondo, 2006, Pullan, Bhasib \& Madhuc, 2010) instead focused on how to organise the supply chain from the earliest stages of the product development process. 


\subsection{Research Hypothesis}

Bernhart, Dressler and Tóth (2010) argued that large engineering-service outsourcing providers are mostly utilised to develop and, to some extent, produce entire vehicle production lines. In fact, it is more efficient for OEMs to ask an external supplier to take over the production of a new vehicle in an existing plant than to build a new production facility. The Nationale Plattform Elektromobilität (NPE) (2010) found that it is necessary to develop flexible production lines to meet the requirements of large-series automotive production. Risch, Guenther and Franke (2012) indicated that to integrate EVs into traditional production lines, several adaptations are needed depending upon the type of EV. According to Bernhart et al. (2010), the automotive industry has to shift from vertically integrated OEMs conducting design, manufacturing and assembly to a buyer-vendor based approach with a multi-tier supplier structure. In addition, they noted that outsourcing would occur even more frequently in the near future due to the lack of adequate know-how. Moreover, intensive engineering outsourcing and off shoring will be favoured by the tight cost-to-target imposed by OEMs.

Some authors (Müller, 2011; Lanza, Stoll, Koelmel \& Peters, 2012) have indicated that OEMs and suppliers must cooperate deeply to ensure that value-added activities continue to be carried out. For example, alliances and joint ventures can provide manufacturers access to know-how, technology, and production capacity from battery suppliers. However, there is a risk that car manufacturers cannot be able to react quickly to the innovations of other battery manufacturers, which would therefore limit the advantages of the economic scale effects (Enrietti \& Patrucco, 2011).

As a result, the following research hypothesis has been formulated to determine the need for changes to be made to the supply chain:

\section{$H_{1}$. The introduction of an EV implies changes in the traditional automotive supply chain.}

Many studies (Byrne \& Polonsky, 2001; Schlick, Hertel, Hagemann \& Maiser, 2011; Franke, 2011; Harikumaran, 2012) argued that some issues, such as the low energy density and weight of batteries, could notably limit the driven autonomy of EVs. Battery charging usually takes several hours, but a quick recharge or the possibility of replaceable batteries at proper service stations might help to solve this problem. The lack of charging stations is also a serious factor preventing the market penetration of EVs. In this case, charging stations in homes, workplaces, and indoor public places would be needed. In this regard, there are a sufficient number of accessible charging points in some European countries, but no policies are in place to develop an adequate charging infrastructure network.

Karplus, Paltsev and Reilly (2010) suggested that a plug-in hybrid electric vehicle (PHEV) would cost from $30 \%$ to $80 \%$ over an internal combustion engine vehicle (ICEV). According to Ernst and Pieper 
(2012), a battery electric vehicle (BEV) can worth about 63\% more value added as compared to an ICEV. The high cost of batteries represents the principal problem to the diffusion of EVs. Such value added is also due to the cost of the high-speed flywheel assembly. According to Flybrid Systems (2009) cost estimates, which were based on mainstream automotive market production volume, the standard flywheel should cost between $\$ 1,000$ and $\$ 3,000$, whereas the continuously variable transmission should cost no more than $\$ 1,500$. Therefore, the complete flywheel system should cost between $\$ 2,500$ and $\$ 4,500$.

Based on the above discussion the following research hypotheses have been formulated:

\section{$H_{2}$. The higher cost of an EV is associated with the criticality of some components.}

\section{$H_{3 .}$ Companies invest limited resources in the EV market due to technological issues related to the electrical powertrain.}

Several studies analysed the impact of monetary incentives on sales of EVs. Diamond (2009) observed that there is a weak relationship between incentive policies and the adoption of hybrid electric vehicles (HEVs). This was attributed to the fact that dealers factor state incentives into their pricing structure and charge consumers more for the vehicles (Diamond, 2009). In this case, monetary incentives only serve as a subsidy to automobile dealers (contrary to policymakers' aims) without significantly increasing EV adoption by users. According to Eppstein, Grover, Marshall and Rizzo (2011), temporary incentive programs are not likely to have long-term effects unless manufacturers are able to reduce sticker prices when the incentives end. Conversely, upfront incentives can help to accelerate the market penetration of EVs (Christidis, Hidalgo \& Soria, 2003). Other studies (Potoglou \& Kanaroglou, 2007; Chandra, Gulati \& Kandilikar, 2010; Sierzchula, Bakker, Maat \& van Wee, 2014) pointed out that individuals are more attracted to "tax-free" incentives. These considerations lead to define this final hypothesis:

\section{$H_{4}$. The type of incentive influences $E V$ diffusion.}

\section{Methodology}

\subsection{Questionnaire Layout}

The first step of this study was to design a questionnaire to assess the necessary changes for the introduction of EVs to the traditional automotive supply chain. Direct interviews were carried out with representatives of logistics and engineering divisions to identify the relevant elements of the supply chain during the trade fair for sustainable mobility "Klimamobility 2012" held in Bolzano, Italy, in 2012. According to the surveyed companies, 10 main elements were identified related to the economic, logistical and human aspects: 
- Customers

- Suppliers. These elements analyse the necessity to establish ties with new customers and suppliers.

- Workers. The possibility to train current workers or to hire new skilled ones is considered.

- Production capacity (e.g., man-hours, machine hours)

- Production lines

- Production facilities

- R\&D. They included some aspects concerning the "make or buy" strategy; this represents the choice of a company to fabricate components and/or products in-house (make) or to buy them from outside (buy). This decision includes specific groups of activities needed for production, such as R\&D. These activities regards personnel, material, and financial resources dedicated to the study of technological innovations needed to improve existing products, fabricate new products, or improve production processes.

- Marketing

- Transition to an agile supply chain. The transition to an agile supply chain was a further aspect considered in the questionnaire. Agility concerns organisational structures, information systems, logistics processes, and, in particular, the mental attitude of managers (Aitken, Christopher \& Towill, 2002). A key feature of agile organisations is flexibility (Halla, Skipperb \& Hannac, 2010; Chiang, Kocabasoglu-Hillmer \& Suresh, 2012); an agile supply chain can be defined as the use of commercial knowledge in the organisation of the supply chain to take advantage of business opportunities in a market with highly variable demand (Naylor, Naim \& Berry, 1997).

- Collaboration agreements. Collaboration agreements in the form of joint ventures can represent a major change for suppliers and companies operating in the automotive sector. A joint venture is an agreement between two or more companies; their joining defines a new legal entity. Companies that agree to work together have as their aim the creation of an industrial or commercial common project that involves the synergetic use of resources of each individual participating company (Binder \& Clegg, 2007). It also involves a certain amount of risk sharing related to investments, money losses and gains. Moreover, different knowledge bases and levels of capital can be shared to realise joint investments.

The questionnaire, in its final form, consisted of five sections (see the scheme provided in Appendix 1):

- Section 1. Examination of general aspects about the surveyed enterprise (enterprise size and market segment and role of the respondents);

- Section 2. Probing potential changes to the automotive supply chain when EVs are considered. This section also examine how much attention is paid to the key supply chain processes stated by Lambert (2008); 
- Section 3. The enterprise's perception is evaluated regarding certain market aspects such as the most diffuse EVs and body styles;

- Section 4. Respondents indicate the criticality level of some car components and features;

- Section 5. Examination of the role and the importance of various types of incentives such as purchase price, road tax, car insurance, rebates on fuel prices, and tax-holidays.

\subsection{Data Collection}

The second step of the research was to identify the statistical sample of enterprises to be surveyed. Several available databases were explored:

- EVtransPortal (www.evtransportal.org) is a non-profit organisation dedicated to helping people around the globe to find sustainable transport through electric drive vehicle technology;

- Europages (www.europages.it) is a leading enterprise in the activation of business-to-business contacts in Europe. Its website references over two million suppliers including manufacturers, service providers, wholesalers, and distributors.

By consulting the above databases, 816 Italian companies operating in the automotive sector were identified. These companies were contacted with an email that included a link to the Google Docs questionnaire and an attached cover letter explaining the aims of this study. The data collection began in September 2012 and lasted four months. Due to the nature of the topics at hand, the questionnaire was addressed to project managers, marketing managers, and operation managers. Moreover, respondents were invited to deliver the questionnaire to the most appropriate business functions. Overall, 115 questionnaires were collected, and 113 were valid in terms of further statistical analysis; the average response rate of approximately 13.8\% (= 113/816), although limited, may be considered suitable for a survey analysis (Yu \& Cooper, 1983). Questionnaire parameters were preliminarily assessed by computing Cronbach's alpha coefficient. The results produced an alpha coefficient of 0.908 , which is above the recommended value of 0.7 as stated by Nunnally (1978).

\subsection{Statistical Analysis}

A descriptive statistics analysis was carried out to provide an overview of the sample of enterprises surveyed. This analysis was performed on the questions of section 1 of the questionnaire. Then, a combination of a confirmatory factor analysis (CFA) and a cluster analysis was performed on the answers of section 2 . The aim was to identify the potential changes to the supply chain that should be adopted by enterprises when 
introducing EVs in a traditional automotive supply chain. The potential changes were obtained through an analysis of 16 items. CFA is used to test whether measures of a factor are consistent with a researcher's understanding of the nature of that factor. The aim of CFA is to test whether the data fit a hypothesised measurement model. This hypothesised model is based on theory and/or previous analytical research (Preedy \& Watson 2009). CFA was expected to be correctly executed according to the "Rule of 100" proposed by Kline (1979) and Gorsuch (1983) (i.e., the number of gathered responses should not be less than 100 even if the number of variables is less than 20) and Hatcher (1994) (i.e., the number of gathered responses should be larger than 5 times the number of variables). To estimate the reliability of each factor, Cronbach's alpha coefficients were computed. Once the factors were determined, the performance of companies regarding each factor was calculated by exploiting the responses of each respondent against the different aspects composing a factor. As a result, several performance values related to the different factors identified were defined for each company. As the number of clusters was not known a priori, the data obtained were analysed through multivariate analysis by employing a hierarchical cluster analysis in accordance with Ward's method. The distances among samples were calculated as square Euclidean distances. Dendrogram similarity scales ranged from zero (greater similarity) to 25 (lower similarity) were defined. Major details to define each cluster were obtained after examining some selected questions of sections 1 (e.g., company size and industry field) and 2 (e.g., supply chain changes and key supply chain processes) with contingency tables. Finally, a descriptive analysis was performed on questions of sections 3 , 4 and 5 of the questionnaire. All of the analyses were performed with IBM SPSS (Statistical Package for the Social Sciences), which is a tool used for survey authoring and deployment (IBM SPSS Data Collection), data mining (IBM SPSS Modeler), text analytics, statistical analysis, and collaboration and deployment.

\section{Survey Results}

\subsection{Characteristics of Enterprises}

According to the Commission Recommendation 2003/361/EC of $6^{\text {th }}$ May 2003, surveyed enterprises were grouped into micro- (<10 employees), small-medium- (11-250 employees), and large-sized enterprises ( $>250$ employees). The number and size of the surveyed enterprises is listed in Table 1.

\begin{tabular}{|l|r|r|}
\hline Enterprise size & $\mathbf{N}$ & \multicolumn{1}{l|}{$\%$} \\
\hline micro & 51 & $45.1 \%$ \\
\hline small - medium & 43 & $38.1 \%$ \\
\hline large & 19 & $16.8 \%$ \\
\hline
\end{tabular}

Table 1. Descriptive statistics analysis: size of the surveyed companies 
Descriptive statistics analysis performed on question 2 (Table 2) reveals that the sample surveyed consists of several types of industries; this increases the generality of the survey results (Malhotra \& Grover, 1998). Specifically, the sample mainly included companies operating as automotive suppliers (54.0\%) and as research \& development entities (16.8\%). Table 2 also shows that $10.6 \%$ of respondents were energy suppliers and $7.0 \%$ operated in the charging stations field.

\begin{tabular}{|l|r|r|}
\hline Industry field & $\mathbf{N}$ & \multicolumn{1}{|c|}{$\%$} \\
\hline Automotive suppliers & 61 & $54.0 \%$ \\
\hline Research \& development & 19 & $16.8 \%$ \\
\hline Energy suppliers & 12 & $10.6 \%$ \\
\hline Vehicle manufacturers & 9 & $8.0 \%$ \\
\hline Charging stations & 8 & $7.0 \%$ \\
\hline Other & 4 & $3.6 \%$ \\
\hline
\end{tabular}

Table 2. Descriptive statistics analysis: industry sectors of the surveyed companies

The last question of section 1 asked respondents to indicate their job within the company. As mentioned before, the questionnaire was addressed to project, operation or marketing managers, which in most cases $(61.0 \%)$ were individuals who responded to the survey (Table 3). In other cases, respondents were CEO $(23.9 \%)$, technical managers $(8.0 \%)$ or designers $(7.1 \%)$.

\begin{tabular}{|l|r|r|}
\hline Role of the respondent & N & \multicolumn{1}{|c|}{$\%$} \\
\hline Project manager & 44 & $38.9 \%$ \\
\hline CEO & 27 & $23.9 \%$ \\
\hline Operation manager & 14 & $12.4 \%$ \\
\hline Marketing manager & 11 & $9.7 \%$ \\
\hline Technical manager & 9 & $8.0 \%$ \\
\hline Designer & 8 & $7.1 \%$ \\
\hline
\end{tabular}

Table 3. Descriptive statistics: role of the respondent to the questionnaire

\subsection{Questions About Enterprises Policies}

Section 2 of the questionnaire aimed to identify the possible levels of change of a supply chain by a CFA. Respondents were asked to specify their level of agreement or disagreement on 16 different items following a 5-point Likert scale. This psychometric scale, which is commonly used in research employing questionnaires, was given the following values: 1 = very unimportant; 2 = unimportant; 3 = indifferent; 
$4=$ important; and $5=$ very important. The 16 items were identified according to the surveyed enterprises during the trade fair "Klimamobility 2012" and divided into three main categories (question 4):

1. minor changes (5 items hypothesised);

2. major changes (5 items hypothesised);

3. radical/total changes (6 items hypothesised).

CFA and reliability analyses were performed on these categories. The results are listed in Table 4 and Appendix 2.

\begin{tabular}{|l|r|}
\hline Factor description & Loading \\
\hline $\begin{array}{l}\text { FACTOR 1 - minor changes to the supply chain } \\
\text { (alpha } \mathbf{0 . 8 6 0 )}\end{array}$ & .843 \\
\hline aspect 1 = Suppliers will adapt to the demand for new products & .788 \\
\hline aspect 2 = Modify the existing production lines for new products & .807 \\
\hline aspect 3 = Modify the production capacity (e.g., man-machine hours) & .832 \\
\hline aspect 4 = Internal training for workers & .877 \\
\hline aspect 5 = Internal research and development for new products &
\end{tabular}

FACTOR 2 - major changes to the supply chain

$($ alpha $=0.921)$

\begin{tabular}{l|r|} 
aspect 1 = Change some suppliers & .923 \\
\hline aspect 2 = Add new production lines to existing & .893 \\
\hline aspect 3 = Partial outsourcing & .879 \\
\hline aspect 4 = Recruitment of new skilled workers & .907 \\
\hline aspect 5 = Establish relationships with new customers & .908
\end{tabular}

FACTOR 3 - radical and total changes to the supply chain

$($ alpha $=0.897)$

\begin{tabular}{|l|r|}
\hline aspect 1 = Totally new suppliers & .865 \\
\hline aspect 2 = Create new production facilities & .875 \\
\hline aspect 3 = Total outsourcing & .885 \\
\hline aspect $4=$ Transition to an agile supply chain & .871 \\
\hline aspect 5 = External research and development for new products & .886 \\
\hline aspect 6 - Consider collaboration agreements such as a joint venture & .886 \\
\hline
\end{tabular}

Table 4. CFA and reliability analyses using Cronbach's alpha coefficient

CFA confirms that the hypothesised categories capture all of the aspects included in the survey. In fact, all of the aspects have sufficient reliability because Cronbach's alpha coefficient is always above 0.7, and the loadings are also high enough as they are above 0.6. 


\subsection{Cluster Analysis}

As a further step, the score obtained for each respondent was calculated against the three factors identified above; the average of the numerical values of the enterprises' answers provided for each item included in the factor was used to obtain the final score. Because of the 5-point Likert scale, the score could range from 1 to 5 . Based on the scores obtained, the sample of respondents was then clustered into different groups that were used as clustering variables. As the number of clusters was not known a priori, an agglomerative hierarchical clustering method was used with Ward's algorithm and a squared Euclidean distance measure to generate the initial cluster subtypes (Milligan \& Cooper, 1987). A cubic clustering criterion and ANOVA were used to determine the number of cluster solutions and to show which clusters were well-defined (Milligan \& Cooper, 1985). The clustering procedure identified three clusters (Table 5) and correctly categorised all the elements of the sample.

\begin{tabular}{|c|c|c|c|c|}
\hline \multirow[t]{2}{*}{ Cluster } & \multirow{2}{*}{$\begin{array}{l}\text { Number of } \\
\text { elements }\end{array}$} & $\begin{array}{l}\text { FACTOR } 1 \\
\text { minor changes }\end{array}$ & $\begin{array}{l}\text { FACTOR } 2 \\
\text { major changes }\end{array}$ & $\begin{array}{l}\text { FACTOR } 3 \\
\text { radical/total changes }\end{array}$ \\
\hline & & Mean & Mean & Mean \\
\hline 1 & $55(48.7 \%)$ & 3.92 & 3.11 & 2.46 \\
\hline 2 & $43(38.0 \%)$ & 3.50 & 4.14 & 3.19 \\
\hline 3 & $15(13.3 \%)$ & 3.04 & 3.68 & 3.84 \\
\hline \multirow{2}{*}{ ANOVA } & $\mathrm{F}$ & 29.644 & 91.712 & 87.012 \\
\hline & Sig & .000 & .000 & .000 \\
\hline
\end{tabular}

Table 5. The results of cluster analysis and cluster centres

Cluster 1 includes the highest number of respondents (42), which corresponds to $48.7 \%$ of the investigated companies. Such respondents show a higher performance against factor 1 whereas a lower score is obtained against factor $2(38.0 \%)$ and factor $3(13.3 \%)$. Therefore, companies from cluster 1 privilege minor changes to the supply chain and pay limited attention to other major changes.

In cluster 2, companies show very high performance against factor 2 and a moderately high score against factor 1 , this indicates a slight stronger prescription to change the supply chain than cluster 1 .

Cluster 3 includes the smallest number of companies (12). Such respondents are characterised by a high performance against factors 2 and 3, this indicates that a mix of major and radical/total changes are needed to introduce EVs into the traditional supply chain. 


\subsection{Cluster Profile: Contingency Tables}

Further analyses were carried out by means of contingency tables to investigate more deeply the characteristics of each cluster. These statistical tables correlate clusters to the questions of sections 1 (e.g., company size and industry field) and 2 (e.g., key supply chain processes). Table 6 shows the ensuing relationships between company size and clusters.

\begin{tabular}{|c|c|c|c|c|}
\hline \multirow{2}{*}{ Enterprise size } & \multicolumn{4}{|c|}{ Number of respondents } \\
\hline & Cluster 1 & Cluster 2 & Cluster 3 & Total \\
\hline micro & $45(88.2 \%)$ & $5(9.8 \%)$ & $1(2.0 \%)$ & $51(100 \%)$ \\
\hline small - medium & $10(23.2 \%)$ & $33(76.8 \%)$ & - & $43(100 \%)$ \\
\hline large & - & $5(26.3 \%)$ & $14(73.7 \%)$ & $19(100 \%)$ \\
\hline Total & 55 & 43 & 15 & 113 \\
\hline \multirow{2}{*}{ CHI SQUARE } & $\chi^{2}$ & \multicolumn{3}{|r|}{43.678} \\
\hline & Sig & & & .000 \\
\hline
\end{tabular}

Table 6. Contingency table: clusters vs. company size

Note that cluster 1 mainly includes micro-sized companies (88.2\%) and SMEs (23.2\%). Cluster 2 is composed of $76.8 \%$ SMEs, $26.3 \%$ large-sized companies, and $9.8 \%$ micro-sized companies whereas cluster 3 includes 73.7\% large-sized companies and only 1 micro-sized company (2.0\%). Company size might be one conceivable explanation of different clusters' performances against the changes to the supply chain needed for the introduction of EVs. In fact, large-sized companies have the most complex and longest supply chains, where more important changes are most likely to be applied.

Table 7 shows the relationships between the industry fields and the related clusters.

As reported, the industry fields are quite homogeneously distributed among all clusters. Thus, there are no significant differences between the industry fields represented among clusters.

An effective supply chain management requires changes that begin from managing single functions to the integration of key processes in the supply chain (Peck, 2006). One possible scenario occurs when the purchasing function prepares orders in line with demand and the marketing meets customers' needs in communication with distributors and retailers. The information can be shared among various actors in the supply chain only if the processes involved are fully integrated. According to Lambert and Cooper (2000), a continuous flow of information to support the corresponding flow of products is required to build an integrated supply chain. Lambert identified the key elements to be integrated into the supply chain: customer relationship management, customer service management, demand management style, 
manufacturing flow management, order fulfilment, product development and commercialisation, returns management, and supplier relationship management.

\begin{tabular}{|c|c|c|c|c|}
\hline \multirow{2}{*}{ Industry field } & \multicolumn{4}{|c|}{ Number of respondents } \\
\hline & Cluster 1 & Cluster 2 & Cluster 3 & Total \\
\hline Automotive suppliers & 38 & 22 & 1 & 61 \\
\hline Research \& development & 7 & 7 & 5 & 19 \\
\hline Energy suppliers & 4 & 4 & 4 & 12 \\
\hline Vehicles manufacturers & 1 & 4 & 4 & 9 \\
\hline Charging stations & 3 & 4 & 1 & 8 \\
\hline Other & 2 & 2 & - & 4 \\
\hline Total & 55 & 43 & 15 & 113 \\
\hline \multirow{2}{*}{ CHI SQUARE } & $\chi^{2}$ & \multicolumn{3}{|r|}{13.436} \\
\hline & Sig & & & .203 \\
\hline
\end{tabular}

Table 7. Contingency table: clusters vs. industry field

According to Devaraja (2011) and pre-surveyed enterprises (communications during the trade fair "Klimamobility 2012”), other key critical supply chain processes are outsourcing/partnerships, performance measurement, and warehousing management. Key supply chain processes were also taken into account in the cluster analysis. The results are reported in Table 8 in terms of the average response observed for each cluster.

From Table 8, the companies of cluster 3 systematically dominate the other clusters as they obtained the highest scores against all of the proposed key supply chain processes (greater than 3.5 against 10 out of the 11). This indicates that these companies pay a lot of attention to these key supply chain processes and confirms their broad overview of the entire supply chain. Companies of cluster 2 have obtained intermediate scores ranging from 2.83 for warehousing management to 4.43 for customer service management, the latter being considered the most important process by all three clusters. Moreover, only 6 out of 11 of the key supply chain processes proposed have obtained scores higher than 3.5 for this cluster. Finally, companies of cluster 1 exhibit the lowest values against all the processes, although they are not so different from those of cluster 2. Supplier relationship management (2.83) and returns management (2.60) are the processes with the largest differences compared to cluster 2 . 


\begin{tabular}{|l|r|r|r|r|r|r|}
\hline Key supply chain processes & Cluster 1 & Cluster 2 & Cluster 3 & $\begin{array}{c}\text { Overall weighted } \\
\text { average }\end{array}$ & $\chi^{2}$ & Sig. \\
\hline Customer service management & 4.27 & 4.43 & 4.52 & 4.37 & 28.835 & .000 \\
\hline $\begin{array}{l}\text { Customer relationship } \\
\text { management }\end{array}$ & 4.25 & 4.32 & 4.33 & 4.28 & 27.759 & .001 \\
\hline $\begin{array}{l}\text { Product development and } \\
\text { commercialisation }\end{array}$ & 4.00 & 4.01 & 4.05 & 4.01 & 59.153 & .000 \\
\hline Performance measurement & 3.64 & 3.83 & 4.11 & 3.79 & 47.549 & .000 \\
\hline Order fulfilment & 3.55 & 3.67 & 3.84 & 3.65 & 20.836 & .022 \\
\hline Manufacturing flow management & 3.36 & 3.50 & 3.89 & 3.50 & 40.950 & .000 \\
\hline Demand management style & 3.33 & 3.36 & 3.88 & 3.44 & 38.612 & .000 \\
\hline Outsourcing/partnerships & 3.00 & 3.17 & 3.91 & 3.22 & 35.947 & .000 \\
\hline Supplier relationship management & 2.83 & 3.22 & 3.82 & 3.15 & 37.786 & .000 \\
\hline Returns management & 2.60 & 3.11 & 3.83 & 3.01 & 19.872 & .011 \\
\hline Warehousing management & 2.73 & 2.83 & 3.13 & 3.84 & 36.876 & .000 \\
\hline \multicolumn{1}{|c|}{ Average } & 3.41 & 3.59 & 3.94 & 3.57 & \\
\hline
\end{tabular}

Table 8. Contingency table: clusters vs. key supply chain processes

\subsubsection{Cluster Profile: Further Consideration}

Further considerations can be derived when all outcomes that make up the three main clusters are examined for each cluster (Table 9).

As regards the first group (minor changes to the supply chain), all the proposed aspects obtain a very high score ( $\geq 3.5$ out of a total score of 5 ) according to the companies in the cluster 1 . Some aspects such as "internal research and development for new products", "suppliers will adapt to the demand for new products" and "internal training for workers" are characterised by high scores from cluster 2; however, 4 out of 5 items obtained a sufficient score $(>3)$. Scores from companies in cluster 3 confirm the importance of the first listed aspects with respect to the other ones.

The judgments expressed by companies in cluster 1 against the topics listed in the second group show high scores only against $40 \%$ of the proposed items (e.g., "establish relationships with new customers" and "change some suppliers"). Companies of cluster 2 show very high scores against all the listed items especially regarding the importance of establishing relationships with new customers (4.67/5). These results are confirmed, albeit to a lesser extent, from the companies in cluster 3. The lowest score is represented by the need to change some suppliers (3.21/5). 


\begin{tabular}{|c|c|c|c|c|c|c|c|}
\hline & & $\begin{array}{c}\text { Cluster } \\
1\end{array}$ & $\begin{array}{l}\text { Cluster } \\
2\end{array}$ & $\begin{array}{c}\text { Cluster } \\
3\end{array}$ & $\begin{array}{c}\text { Overall } \\
\text { weighted } \\
\text { average }\end{array}$ & $\chi^{2}$ & Sig. \\
\hline \multirow{6}{*}{$\begin{array}{l}\text { Minor changes to } \\
\text { the supply chain }\end{array}$} & $\begin{array}{l}\text { Internal research and development } \\
\text { for new products }\end{array}$ & 3.92 & 4.13 & 4.07 & 4.02 & 18.629 & .045 \\
\hline & Internal training for workers & 4.42 & 3.83 & 2.92 & 3.99 & 41.376 & .000 \\
\hline & $\begin{array}{l}\text { Suppliers will adapt to the demand } \\
\text { for new products }\end{array}$ & 3.75 & 4.01 & 3.58 & 3.83 & 38.090 & .000 \\
\hline & $\begin{array}{l}\text { Modify the existing production lines } \\
\text { for new products }\end{array}$ & 3.92 & 3.33 & 3.30 & 3.61 & 51.343 & .000 \\
\hline & $\begin{array}{l}\text { Modify the production capacity (e.g., } \\
\text { man-hours, machine hours) }\end{array}$ & 3.58 & 2.83 & 2.61 & 3.16 & 20.235 & .009 \\
\hline & Average value & 3.92 & 3.63 & 3.30 & 3.72 & & \\
\hline \multirow{6}{*}{$\begin{array}{l}\text { Major changes to } \\
\text { the supply chain }\end{array}$} & $\begin{array}{l}\text { Establish relationships with new } \\
\text { customers }\end{array}$ & 3.83 & 4.67 & 4.12 & 4.19 & 45.862 & .000 \\
\hline & Change some suppliers & 3.58 & 4.17 & 3.21 & 3.75 & 47.400 & .000 \\
\hline & Add new production lines to existing & 2.50 & 4.18 & 3.52 & 3.28 & 28.883 & .001 \\
\hline & Recruitment of new skilled workers & 2.42 & 3.83 & 3.73 & 3.14 & 57.011 & .001 \\
\hline & Partial outsourcing & 2.43 & 3.83 & 3.53 & 3.11 & 16.447 & .036 \\
\hline & Average value & 2.95 & 4.14 & 3.62 & 3.49 & & \\
\hline \multirow{7}{*}{$\begin{array}{l}\text { Radical and total } \\
\text { changes to the } \\
\text { supply chain }\end{array}$} & $\begin{array}{l}\text { External research and development } \\
\text { for new products }\end{array}$ & 3.42 & 4.00 & 4.06 & 3.73 & 119.186 & .000 \\
\hline & $\begin{array}{l}\text { Considering collaboration } \\
\text { agreements such as a joint venture }\end{array}$ & 3.17 & 3.48 & 3.57 & 3.34 & 80.365 & .000 \\
\hline & Transition to an agile supply chain & 2.17 & 3.17 & 4.13 & 2.84 & 25.237 & .005 \\
\hline & Create new production facilities & 1.83 & 2.84 & 4.20 & 2.54 & 73.116 & .000 \\
\hline & Totally new suppliers & 1.58 & 2.83 & 4.22 & 2.42 & 26.210 & .003 \\
\hline & Total outsourcing & 2.08 & 2.33 & 2.65 & 2.25 & 30.860 & .001 \\
\hline & Average value & 2.38 & 3.11 & 3.81 & 2.85 & & \\
\hline
\end{tabular}

Table 9. Clusters vs. changes to the supply chain. Outcomes are reported in terms of the average judgment

As regards the last group, cluster 1 obtains low scores against $67 \%$ of the proposed items. Only two aspects ("external research and development for new products" and "considering collaboration agreements as a joint venture") have obtained a sufficient score. Cluster 2 also produces low scores against most of the proposed items (5 out of 6). However, these companies consider cluster 2 very important to entrust the research and development for new products to external firms (4.00/5). Regarding cluster 3, it emerges that companies pay a greater attention to almost all the topics listed because the average importance judgment expressed by this cluster is always higher than 3.5. Only the concept of total outsourcing exhibits value below $3.5(2.65 / 5)$. 


\subsection{Questions About Vehicles}

Questions 6 and 7 of section 3 asked respondents to indicate which type of EV their company is mainly investing on and which body styles they are developing as an EV. The ensuing results are listed in Table 10. BEVs are the most popular investment for $80 \%$ of micro-sized companies, $60.5 \%$ of SMEs, and $57.1 \%$ of large-sized companies, whereas $12.7 \%$ of micro-sized companies, $39.5 \%$ of SME, and $20 \%$ of large-sized companies are investing in HEVs. Note that $21.4 \%$ of large-sized companies are also investing PHEVs. Furthermore, all companies, regardless of size, exhibit an interest in city cars within limits: 12.7\% of micro-sized companies and 7\% of SMEs are also investing in coupes/roadsters, whereas large-sized companies are investing in sedans.

\begin{tabular}{|c|c|c|c|}
\hline \multirow{2}{*}{ Electric vehicle } & \multicolumn{3}{|c|}{ Company size } \\
\hline & Micro & SME & Large \\
\hline $\mathrm{HEV}$ & $7(12.7 \%)$ & $17(39.5 \%)$ & $3(20 \%)$ \\
\hline PHEV & 0 & 0 & $3(20 \%)$ \\
\hline $\mathrm{BEV}$ & $44(80 \%)$ & $26(60.5 \%)$ & $8(53.3 \%)$ \\
\hline \multirow[t]{2}{*}{ Other } & $4(7.3 \%)$ & 0 & $2(13.3 \%)$ \\
\hline & 55 & 43 & 15 \\
\hline \multicolumn{4}{|l|}{ Body Style } \\
\hline city car & $55(100 \%)$ & $43(100 \%)$ & $15(100 \%)$ \\
\hline sedan & $4(7.3 \%)$ & 0 & $3(20 \%)$ \\
\hline station wagon & 0 & 0 & 0 \\
\hline multi-purpose vehicle & 0 & 0 & 0 \\
\hline suv & 0 & 0 & 0 \\
\hline coupe/roadster & $7(12.7 \%)$ & $3(7.0 \%)$ & 0 \\
\hline
\end{tabular}

Table 10. Descriptive statistics analysis: questions 6 and 7

Question 8 of the questionnaire asked respondents to indicate whether the market creates an environment that encourages innovation in EVs, whereas question 9 asked the degree of importance that the respondent would attribute to the EV market. According to Table 11, 50.9\% of micro-sized companies, $67.4 \%$ of SMEs, and $33.3 \%$ of large-sized companies do not completely agree that the current market creates an environment that encourages innovations in EVs. Despite these results, 92.7\% of micro-sized companies, $69.8 \%$ of SMEs, and 53.5\% of large-sized companies attribute a high degree of importance to the EV market. 


\begin{tabular}{|c|c|c|c|c|c|c|c|}
\hline \multicolumn{3}{|l|}{ Judgment } & $\begin{array}{c}1 \\
\text { (strongly disagree) }\end{array}$ & 2 & 3 & 4 & $\begin{array}{c}5 \\
\text { (strongly agree) }\end{array}$ \\
\hline \multirow{6}{*}{$\begin{array}{l}\text { The market creates an } \\
\text { environment that } \\
\text { encourages innovation } \\
\text { in electric vehicles }\end{array}$} & \multirow{2}{*}{ Micro } & $\mathrm{N}$ & 4 & 14 & 10 & 18 & 9 \\
\hline & & $\%$ & $7.3 \%$ & $25.4 \%$ & $18.2 \%$ & $32.7 \%$ & $16.4 \%$ \\
\hline & \multirow{2}{*}{ SME } & $\mathrm{N}$ & 0 & 7 & 22 & 7 & 7 \\
\hline & & $\%$ & - & $16.3 \%$ & $51.1 \%$ & $16.3 \%$ & $16.3 \%$ \\
\hline & \multirow{2}{*}{ Large } & $\mathrm{N}$ & 0 & 2 & 3 & 7 & 3 \\
\hline & & $\%$ & - & $13.3 \%$ & $20 \%$ & $46.7 \%$ & $20 \%$ \\
\hline \multicolumn{3}{|l|}{ Judgment } & $\begin{array}{c}1 \\
\text { (very unimportant) }\end{array}$ & 2 & 3 & 4 & $\begin{array}{c}5 \\
\text { (very important) }\end{array}$ \\
\hline \multirow{6}{*}{$\begin{array}{l}\text { Degree of importance } \\
\text { that respondents } \\
\text { attribute to the electric } \\
\text { vehicle market }\end{array}$} & \multirow{2}{*}{ Micro } & $\mathrm{N}$ & 0 & 0 & 4 & 6 & 45 \\
\hline & & $\%$ & - & - & $7.3 \%$ & $10.9 \%$ & $81.8 \%$ \\
\hline & \multirow{2}{*}{ SME } & $\mathrm{N}$ & 0 & 0 & 13 & 8 & 22 \\
\hline & & $\%$ & - & - & $30.2 \%$ & $18.6 \%$ & $51.2 \%$ \\
\hline & \multirow{2}{*}{ Large } & $\mathrm{N}$ & 0 & 1 & 6 & 3 & 5 \\
\hline & & $\%$ & - & $6.7 \%$ & $40 \%$ & $20 \%$ & $33.3 \%$ \\
\hline
\end{tabular}

Table 11. Descriptive statistics analysis: questions 8 and 9

Question 10 asked respondents their opinion about when the EV market will become predominant with respect to the market of conventional vehicles. The results are listed in Table 12. A transition year of 2050 was declared by $32.7 \%$ of micro-sized companies, whereas $48.9 \%$ of SMEs and $60 \%$ of large-sized companies predict it closer to 2040.

\begin{tabular}{|c|c|c|c|c|c|c|c|}
\hline \multicolumn{3}{|l|}{ Year } & 2020 & 2030 & 2040 & 2050 & Never \\
\hline \multirow{6}{*}{$\begin{array}{l}\text { When will the market for } \\
\text { electric vehicles be } \\
\text { predominant with respect to } \\
\text { the conventional one? }\end{array}$} & \multirow{2}{*}{ Micro } & $\mathrm{N}$ & 10 & 10 & 17 & 18 & 0 \\
\hline & & $\%$ & $18.2 \%$ & $18.2 \%$ & $30.9 \%$ & $32.7 \%$ & - \\
\hline & \multirow{2}{*}{ SME } & $\mathrm{N}$ & 1 & 7 & 21 & 14 & 0 \\
\hline & & $\%$ & $2.3 \%$ & $16.3 \%$ & $48.9 \%$ & $32.5 \%$ & - \\
\hline & \multirow{2}{*}{ Large } & $\mathrm{N}$ & 3 & 3 & 9 & $0 \%$ & 0 \\
\hline & & $\%$ & $20 \%$ & $20 \%$ & $60 \%$ & $0 \%$ & - \\
\hline
\end{tabular}

Table 12. Descriptive statistics analysis: question 10

The last question in section 3 asked respondents to indicate the difference in price between an EV and a conventional vehicle with similar features. The results are listed in Table 13. HEVs will cost $2,000 €-4,000 €$ more than a conventional vehicle according to $46.9 \%$ of respondents whereas $26.5 \%$ declare the difference to be less than 2,000€. PHEVs are expected to cost 4,000€-6,000€ more than a conventional vehicle by $56.7 \%$ of the surveyed companies, whereas $18.6 \%$ declare they will cost 
2,000€-4,000€ more. Finally, $46.9 \%$ and $29.2 \%$ of respondents declared that BEVs will cost more than $10,000 €$ and $6,000 €-10,000 €$ over the price of a conventional vehicle, respectively. BEVs are the most expensive category among the analysed electric vehicles.

\begin{tabular}{|c|r|r|r|r|r|}
\hline Cost difference & \multicolumn{1}{c|}{$<2,000 €$} & $2,000 €-4,000 €$ & $4,000 €-6,000 €$ & $6,000 €-10,000 €$ & $>10,000 €$ \\
\hline HEV & $30(26.5 \%)$ & $53(46.9 \%)$ & $21(18.6 \%)$ & $9(8.0 \%)$ & 0 \\
\hline PHEV & $6(5.3 \%)$ & $21(18.6 \%)$ & $64(56.7 \%)$ & $18(15.9 \%)$ & $4(3.5 \%)$ \\
\hline BEV & $6(5.3 \%)$ & $4(3.5 \%)$ & $17(15.1 \%)$ & $33(29.2 \%)$ & $53(46.9 \%)$ \\
\hline
\end{tabular}

Table 13. Descriptive statistics: Question 11

\subsection{Questions About the Degree of Criticality of Some Components and Features}

Question 12 asked respondents to indicate the degree of criticality of some components and features of an EV. Table 14 shows the obtained results according to the 5-point Likert scale, a value of 1 was assigned to an item that was considered very non-critical whereas a value of 5 indicates it is very critical.

\begin{tabular}{|l|r|}
\hline Item & Mean (S.D.) \\
\hline Battery packs & $4.41(.857)$ \\
\hline Driving range (km with a full tank) & $3.90(1.356)$ \\
\hline Flywheel / transmission & $3.31(1.184)$ \\
\hline Safety in the case of collision & $3.14(1.112)$ \\
\hline Size of the passenger compartment & $2.98(.970)$ \\
\hline Consumption (km / litre) & $2.97(1.280)$ \\
\hline Coefficient of aerodynamic drag (cx) & $2.93(1.104)$ \\
\hline Body frame & $2.62(.852)$ \\
\hline Hi-Tech appearance & $2.28(1.178)$ \\
\hline Acceleration & $2.17(.918)$ \\
\hline Top speed & $2.13(1.025)$ \\
\hline
\end{tabular}

Table 14. Descriptive statistics analysis: Question 12

There are four major critical aspects (>3): battery packs (4.41/5), driving range (3.90/5), flywheel/transmission assembly (3.31\%), and safety in the case of collision (3.14). Conversely, aspects such as top speed (2.13/5), acceleration (2.17/5), and hi-tech appearance (2.28/5) are not considered critical. However, it can be noted that the standard deviation of the results of Table 14 appears to be generally very high (from .852 to 1.356 ). 


\subsection{Questions About Incentives}

At the end of the survey, respondents were asked through a multiple-choice question to indicate whether incentives would promote the diffusion of EVs and the degree of their effectiveness. Five different types of incentives were considered: purchase price, road tax, car insurance, rebates on fuel prices, and tax-holidays. Tables 13 and 14 show the obtained results. The results are reported according to the average judgment expressed by respondents based on a 5-point Likert scale ranging from 1 (= strongly disagree) to 5 (= strongly agree) for Table 15 and from 1 (= very ineffective) to 5 (= very effective) for Table 16.

\begin{tabular}{|l|c|c|c|c|}
\hline \multirow{2}{*}{$\begin{array}{l}\text { Incentives greatly facilitate the } \\
\text { diffusion of electric vehicles }\end{array}$} & $\begin{array}{c}\text { Micro } \\
\text { enterprises }\end{array}$ & $\begin{array}{c}\text { Small-medium } \\
\text { enterprises }\end{array}$ & Large enterprises & $\begin{array}{c}\text { Overall weighted } \\
\text { average }\end{array}$ \\
\cline { 2 - 5 } & $4.08(1.165)$ & $3.83(1.169)$ & $4.27(.786)$ & $4.02(1.101)$ \\
\hline
\end{tabular}

Table 15. Descriptive statistics analysis: Question 13

\begin{tabular}{|l|r|r|r|r|}
\hline \multicolumn{1}{|c|}{ Incentives } & Micro enterprises & $\begin{array}{c}\text { Small-medium } \\
\text { enterprises }\end{array}$ & Large enterprises & $\begin{array}{c}\text { Overall weighted } \\
\text { average }\end{array}$ \\
\hline Purchase price & $4.17(.937)$ & $4.33(.816)$ & $4.45(.820)$ & $4.28(.871)$ \\
\hline Road tax & $3.08(.996)$ & $3.33(1.033)$ & $2.82(1.079)$ & $3.13(1.024)$ \\
\hline Car insurance & $3.25(1.138)$ & $3.17(.753)$ & $2.73(.905)$ & $3.13(.952)$ \\
\hline Rebates on fuel prices & $2.67(1.225)$ & $2.99(1.549)$ & $3.20(1.317)$ & $2.89(1.364)$ \\
\hline Tax-holidays & $2.88(1.126)$ & $2.17(.753)$ & $3.22(1.641)$ & $2.67(1.453)$ \\
\hline
\end{tabular}

Table 16. Descriptive statistics analysis: Question 14

Descriptive statistics analysis performed on the results of Table 15 reveals that all the surveyed companies agree that incentives will notably facilitate the diffusion of EVs. Large-sized companies exhibit the highest score (4.27/5) followed by micro-sized companies (4.08/5) and SMEs (3.83/5). Incentives on the purchase price are considered to be the most effective (4.28/5) especially by large-sized companies $(4.45 / 10)$ and SMEs (4.33/10). Incentives on road taxes and car insurance have a sufficient average score (3.13/5), but are not favoured by large-sized companies (2.83/5 and $2.73 / 5$, respectively). Finally, rebates on fuel prices and tax-holiday incentives do not obtain a sufficient average score (2.89/5 and 2.67/5) although large-sized companies attribute to them a value larger than 3. 


\section{Discussions}

From the data collected and from the statistical analyses, the following conclusions can be drawn. Respondents were asked to indicate their level of agreement or disagreement on 16 different changes to be made to an automotive supply chain; in accordance with the respondents, who operate in the logistics business, the answers were grouped into three main categories: minor, major, radical/total changes. The most important necessary changes to the traditional automotive supply chain are confirmed by a CFA; this analysis also confirms that the hypothesised categories capture all the aspects included in the survey. Surveyed companies were clustered based on their performance against the categories identified above. This analysis can be useful to understand the positioning of companies toward the implementation of the different changes proposed by this study. According to the results, companies can be categorised into three clusters:

- Cluster 1 includes $48.7 \%$ of respondents and shows high performance against factor 1 but only limited alignment with the other factors. This cluster mainly includes micro-sized companies $(88.2 \%)$ and SMEs $(23.2 \%)$ and has produced the lowest scores against the 11 key supply chain processes proposed;

- Cluster 2 includes companies showing very high performance against factor 2 but still with a significant score against factor 1 . The category mainly includes SMEs $(76.8 \%)$ whereas largesized companies and micro-sized companies represent $26.3 \%$ and $9.8 \%$, respectively. As regards the key supply chain processes, cluster 2 has intermediate scores with respect to groups 1 and 2;

- Cluster 3 includes a limited number of companies characterised by high performance against factors 2 and 3. The category includes 73.7\% large-sized companies and only 2.0\% microsized companies. Cluster 3 has obtained the highest scores against all the key supply chain processes proposed, which confirms a broad overview of the entire supply chain.

Micro-sized companies show higher performance against factor 1 and sufficient score against factor 2, whereas lower scores were obtained against factor 3. Therefore, micro-sized companies generally privilege minor changes to the supply chain, whereas they pay limited attention to major changes. These companies indicate that a portion of the production will be outsourced and that only a portion of the actual suppliers will be changed. The current production lines will be modified and new ones will be added without building new production facilities. The activities of research and development and worker training will continue to be internal. 
SMEs show very high performance against factor 2 and a statistically sufficient score against factor 1; this indicates their greater need for changes in the supply chain. SMEs stressed the importance of establishing relationships with totally new customers and suppliers. Like micro-sized companies, they indicate that current production lines will be modified and new lines will be added without building new production facilities; in addition, only part of the production will be outsourced. New skilled workers would be required, and research and development activity will be outsourced.

Large-sized companies are characterised by high performance against factors 2 and 3. These companies argue that a radical change in the automotive supply chain is needed; this may involve adding new production lines to the existing lines and creating new production facilities. Production outsourcing in the case of peak demand will be necessary along with a transition to an agile supply chain to address the variability of demand. Collaboration agreements such as joint ventures should be considered. New skilled workers will be hired and relationships with new suppliers will be established. Finally, research and development activity will be outsourced.

The results of this study indicate that the hypothesis $\mathrm{H}_{1}$ of a relationship between company's size and its attitude to change the traditional automotive supply chain for the introduction of EVs is supported. Smaller companies have less complex logistics management, and logistics appears to be of less overall importance. Spillan, Kohn and McGinnis (2010) also obtained similar findings.

The relationship between the higher cost of an EV and the criticality of some components $\left(\mathrm{H}_{2}\right)$ is also supported in this study. Along these lines, the survey points out that battery pack is considered the most critical component. This is due to its high cost, which can represent up to $63 \%$ more added value (Pannkoke \& Ernst, 2011). Additionally, the weight and volume of batteries are still very high, and their lack of autonomy considerably restricts the driving range of vehicles. Another problem related to the batteries is safety in the case of collision. In fact, Li-ion batteries have a tendency to catch fire and occasionally explode. The flywheel/transmission group is also considered critical. Flywheels store rotational kinetic energy, typically at 40,000-60,000 RPM, so damage to the flywheel housing can cause dangerous accidents. To avoid this issue, advanced and expensive flywheel housings are needed. Other aspects such as hi-tech appearance, vehicle performance, top speed and acceleration are not considered critical.

Assuming an ICEV with a price of 15,000 euros, companies states that HEVs of the same category will be more expensive from 2,000 to 4,000 euros. PHEVs appear to be a little more expensive: the final price will be approximately 4,000-6,000 euros higher than a traditional vehicle of the same car segment. The purchase price of a full EV is by far the most expensive; companies claim that this price will be more than 10,000 euros higher than conventional vehicles on average. 
The hypothesis that companies invest limited resources in the EV market due to the technical nature of the challenges $\left(\mathrm{H}_{3}\right)$ is not supported by this study. On the one hand, the highest percentage of surveyed companies do not completely agree that the current market promotes innovations towards EVs. The reasons are several. There is a considerable lack of confidence among customers due to a lack of information on the product. For many people, an EV appears difficult to use owing to charging and maintenance. The purchase price is still too high. This price point is due to a vicious circle of low quantities. A product that is economically unattractive to customers will generate low economies of scale. In this way, the design and manufacturing costs will be distributed on few produced units. Eventually, all of these costs will be brought to end customers, and the product will be economically unattractive. There is also a lack of policies to promote the use of these vehicles. Finally, charging stations for BEVs and PHEVs are still too few. On the other hand, many companies are still investing resources in the EV market. This is due to several macro factors that have occurred in recent years, such as the rise in oil prices, the need to reduce greenhouse gas emissions, and technological innovations in sectors complementary to the automotive industry (e.g., batteries). The highest percentage of surveyed companies indicate that they are investing in BEVs whereas only a smaller percentage is investing in HEVs. It should be noted that only three large-sized companies declared that they are investing in PHEVs. Companies often see HEVs and PHEVs as transition vehicles on the path to BEVs. Therefore, many companies consider this investment unattractive. Another aspect of this study concerns the analysis of body styles that companies are developing for the fabrication of EVs. Regardless of their size, almost all of the surveyed companies indicate that they are investing in city cars. In fact, city cars have several advantages over the other car segments. First, they are used almost exclusively in cities or at least for short distances, therefore the approximately $200 \mathrm{~km}$ driven range of the current EVs is usually enough. Moreover, city cars can easily be parked due to their small size. They are not noisy and tend to have zero emissions. Overall, micro-sized companies indicate that 2050 will be the transition year between the traditional vehicle transportation and e-mobility, whereas many SMEs and large-sized companies declare 2040. Smaller companies are a little more pessimistic about EV adoption. The previous literature review of Ciarapica et al. (2012) estimated that 2033 as the transition year. According to Owen and Gordon (2002), the EV market will not be significant at least for the next twenty years. However, the studies carried out by Turton and Moura (2008), IEA (2011), and Mock, Hülsebusch, Ungethüm and Schmid (2009) forecast a car market with at least $40 \%$ green vehicles by 2030 . At longer times, notable discrepancies are noted. For example, according to Shepherd, Bonsall and Harrison (2012), the EV market will still be less important than the market for ICEVs (approximately 35\% vs. 65\%), whereas Turton and Moura (2008) and International Energy Agency (IEA) (2011) predicted that EVs would be able to satisfy most user demands by 2035 . 
The survey also indicates that the hypothesis for which the type of incentive influences EV diffusion $\left(\mathrm{H}_{4}\right)$ is supported. The surveyed companies agree that incentives would facilitate considerably the diffusion of EVs. Contrary to what is stated in the literature, incentives on the purchase price are unanimously considered as the most efficient factor promoting the diffusion of EVs, whereas other types of incentives, such as incentives on road taxes or car insurance, only obtained a limited average score.

\section{Conclusions}

This preliminary study has found that the market penetration of EVs is mainly determined by technological choices made by specific manufacturers of vehicles and batteries and by the ability to organise and manage the integrated actions of stakeholders, including car manufacturers, battery manufacturers, component suppliers, and manufacturers of vehicle management systems. To do this, stakeholders have to be able to exploit economies of scale, to make use and expand long-time competencies in electric engineering with automotive know-how, and to build up cooperation with experts in the new value chain to facilitate the required transfer of know-how. Alliances and joint ventures can provide manufacturers access to the know-how, technology, and production capacity of battery suppliers. Outsourcing, especially as regards research and development, will occur even more frequently in the near future. Finally, an agile supply chain should be adopted to manage fluctuating demand especially at the early stages of development.

Suppliers have to cooperate deeply with vehicle manufacturers to ensure that value-added activities continue to be performed. Their strength will be the knowledge advantage concerning key components of the electric drivetrain such as battery packs. Innovation will be the key to successfully differentiate themselves from other suppliers.

Policy makers should improve knowledge transfer among all stakeholders. They also should provide information to businesses and especially to citizens to try to break down initial diffidence. The up-front price should be reduced with monetary incentives, and the charging infrastructure must be built up.

The main findings resulting from this study are grouped into clusters in Figure 1. 


\begin{tabular}{|c|c|c|c|}
\hline & & Changes to the supply chain & \\
\hline & Cluster 1 & Cluster 2 & Cluster 3 \\
\hline & $\uparrow$ minor changes & $\uparrow$ minor changes & $\downarrow$ minor changes \\
\hline & $\downarrow$ several changes & $\uparrow$ several changes & $\uparrow$ several changes \\
\hline & $\downarrow$ radical changes & $\downarrow$ radical changes & $\uparrow$ radical changes \\
\hline Cluster composition & Micro-sized companies & SME & Large-sized companies \\
\hline Most relevant minor changes & $\begin{array}{l}\text { Internal research and } \\
\text { development for new products; } \\
\text { internal training for workers; } \\
\text { suppliers will adapt to the } \\
\text { demand for new products; } \\
\text { modify the existing production } \\
\text { lines for new products; } \\
\text { modify the production capacity } \\
\text { (e.g., man-hours, machine hours) }\end{array}$ & $\begin{array}{l}\text { Internal research and development } \\
\text { for new products; } \\
\text { internal training for workers; } \\
\text { suppliers will adapt to the demand } \\
\text { for new products; }\end{array}$ & $\begin{array}{l}\text { Internal research and development } \\
\text { for new products; } \\
\text { suppliers will adapt to the demand } \\
\text { for new products }\end{array}$ \\
\hline $\begin{array}{l}\text { Most relevant several } \\
\text { changes }\end{array}$ & $\begin{array}{l}\text { Establish relationships with new } \\
\text { customers; } \\
\text { change some suppliers }\end{array}$ & $\begin{array}{l}\text { Establish relationships with new } \\
\text { customers; } \\
\text { change some suppliers; } \\
\text { add of new production lines to } \\
\text { those existing; } \\
\text { recruitment of new skilled } \\
\text { workers; } \\
\text { partial outsourcing }\end{array}$ & $\begin{array}{l}\text { Establish relationships with new } \\
\text { customers; } \\
\text { add of new production lines to those } \\
\text { existing; } \\
\text { recruitment of new skilled workers; } \\
\text { partial outsourcing }\end{array}$ \\
\hline Most relevant radical changes & - & $\begin{array}{l}\text { External research and } \\
\text { development for new products; }\end{array}$ & $\begin{array}{l}\text { External research and development } \\
\text { for new products; } \\
\text { considering collaboration } \\
\text { agreements as a joint venture; } \\
\text { transition to an agile supply chain; } \\
\text { create new production facilities; } \\
\text { totally new suppliers }\end{array}$ \\
\hline $\begin{array}{l}\text { Most important key supply } \\
\text { chain processes }\end{array}$ & $\begin{array}{l}\text { Customer service management; } \\
\text { customer relationship } \\
\text { management; } \\
\text { product development and } \\
\text { commercialization; } \\
\text { performance measurement; } \\
\text { order fulfilment }\end{array}$ & $\begin{array}{l}\text { Customer service management; } \\
\text { customer relationship } \\
\text { management; } \\
\text { product development and } \\
\text { commercialization; } \\
\text { performance measurement; } \\
\text { order fulfilment; } \\
\text { manufacturing flow management }\end{array}$ & $\begin{array}{l}\text { Customer service management; } \\
\text { customer relationship management; } \\
\text { product development and } \\
\text { commercialization; } \\
\text { performance measurement; } \\
\text { order fulfilment; } \\
\text { manufacturing flow management; } \\
\text { demand management style; } \\
\text { outsourcing/partnerships; } \\
\text { supplier relationship management; } \\
\text { returns management }\end{array}$ \\
\hline
\end{tabular}

Figure 1. Summary of the results of the study

\section{References}

Aitken, J., Christopher, M., \& Towill, D. (2002). Understanding, Implementing and Exploiting Agility and Leanness. International Journal of Logistics Research and Applications, 5(1), 59-74. 
Andrews, D., Nieuwenhuis, P., \& Ewing, P.D. (2006). Black and beyond-colour and the mass-produced motor car. Optics \& Laser Technology, 38, 377-391. http://dx.doi.org/10.1016/j.optlastec.2005.06.023

Bernhart, W., Dressler, N., \& Tóth, A. (2010). Mastering Engineering Service Outsourcing in the automotive industry.

http://www.rolandberger.com/media/pdf/Roland_Berger_Mastering_Engineering_Service_Outsourcing_20110215.pdf

Bevilacqua, M., Ciarapica, F.E., Paciarotti, C. (2012). Supply chain integration in an italian automotive company: The case of a kitting system implementation. International Journal of Productivity and Quality Management, 10(4), 428-446. http://dx.doi.org/10.1504/IJPQM.2012.049632

Binder, M., \& Clegg, B. (2007). Designing and managing collaborative enterprises in the automotive industry. International Journal of Logistics Research and Applications, 10(2), 135-152.

http://dx.doi.org/10.1080/13675560701427346

Byrne, M., \& Polonsky, M.J. (2001). Impediments to consumer adoption of sustainable transportation: Alternative fuel vehicles. International Journal of Operations \& Production Management, 21(12), 1521-1538. http://dx.doi.org/10.1108/EUM0000000006293

Caniato, F., \& Größler A. (2015). The moderating effect of product complexity on new product development and supply chain management integration. Production Planning \& Control, 1-12. http://dx.doi.org/10.1080/09537287.2015.1027318

Cao, H., \& Folan, P. (2012). Product life cycle: the evolution of a paradigm and literature review from 1950-2009. Production Planning \& Control, 23(8), 641-662. http://dx.doi.org/10.1080/09537287.2011.577460

Chandra, A., Gulati, S., \& Kandlikar, M. (2010). Green drivers or free riders? An analysis of tax rebates for hybrid vehicles. Journal of Environmental Economics and Management, 60(2), 78-93. http://dx.doi.org/10.1016/j.jeem.2010.04.003

Chiang, C.Y., Kocabasoglu-Hillmer, K., \& Suresh N. (2012). An empirical investigation of the impact of strategic sourcing and flexibility on firm's supply chain agility. International Journal of Operations \& Production Management, 32(1), 49-78. http://dx.doi.org/10.1108/01443571211195736

Christensen, T.B. (2011). Modularised eco-innovation in the auto industry. Journal of Cleaner Production, 19, 212-220. http://dx.doi.org/10.1016/j.jclepro.2010.09.015

Christidis, P., Hidalgo, I., \& Soria, A. (2003). Dynamics of the introduction of new passenger car technologies. The IPTS transport technologies model. JRC Report EUR 20762 EN, Joint Research Centre. Sevilla (Spain). 
Ciarapica, F.E., Matt, D.T., Luccarelli, M., Rossini, M., \& Russo Spena, P. (2012). Factors affecting future scenarios for alternative vehicles market. Advanced Materials Research, 608-609, 1607-1612. http://dx.doi.org/10.4028/www.scientific.net/AMR.608-609.1607

Devaraja, T.S. (2011). Electronic Supply Chain Management and Model Development - Global Perspective. http://sibresearch.org/uploads/2/7/9/9/2799227/sibr___working_paper___scm_final.pdf

Diamond, D. (2009). The impact of government incentives for hybrid-electric vehicles: Evidence from US states. Energy Policy, 37, 972-983. http://dx.doi.org/10.1016/j.enpol.2008.09.094

Duffy, V.G. (2010). Relating company performance to staff perceptions: The impact of concurrent engineering on time to market. International Journal of Production Research, 37(4), 821-834. http://dx.doi.org/10.1080/002075499191544

Enrietti, A., \& Patrucco, P.P. (2011). Systemic innovation and organizational change in the car industry: electric vehicle innovation platforms. Economia e politica industriale, 38(2), 85-106.

Eppstein, M.J., Grover, D.K., Marshall, J.S., \& Rizzo, D.M. (2011). An agent-based model to study market penetration of plug-in hybrid electric vehicles. Energy Policy, 39(6), 3789-3802. http://dx.doi.org/10.1016/j.enpol.2011.04.007

Ernst, C.S., \& Pieper, M. (2012). The development of e-mobility supply chains in Europe. http://www.enevate.eu/ib/site/documents/media/b384eda6-d920-6692-279e-60d30f074343.pdf/14_00_-

Elektromobile Zulieferketten Europa C.pdf

Fine, C. (1998). Clockspeed: Winning Industry control in the age of temporary advantage. Reading, MA: Perseus Books.

Fine, C. (2000). Clockspeed-based strategies for supply chain design. Production and Operations Management, 9(3), 213-221. http://dx.doi.org/10.1111/j.1937-5956.2000.tb00134.x

Fixson, S.K. (2005). Product architecture assessment: a tool to link product, process and supply chain design decisions. Journal of Operations Management, 23(3-4), 345-369.

http://dx.doi.org/10.1016/j.jom.2004.08.006

Flybrid Systems (2009). Available at: www.flybridsystems.com

Franke, J. (2011). Neue Antriebe, neue Montageprozesse, neue Mobilitätskonzepte - Elektromobilität braucht querdenkende Anlagenbauer, VDMA - Infotag Elektromobilität, Frankfurt am Main.

Gorsuch, R.L. (1983). Factor analysis. 2nd edition. Hillsdale, NJ: Erlbaum. 
Halla, D.J., Skipperb, J.B., \& Hannac, J.B. (2010). The mediating effect of comprehensive contingency planning on supply chain organisational flexibility. International Journal of Logistics Research and Applications, 13(4), 291-312. http://dx.doi.org/10.1080/13675561003749247

Hatcher, L. (1994). A Step-by-Step Approach to Using the SAS ${ }^{\circledR}$ System for Factor Analysis and Structural Equation Modelling. Cary, NC: SAS Institute, Inc.

Harikumaran, J. (2012). Sizing and Charge Control Strategies for a Grid-Connected Micro-grid with Electric Vehicles. http://repository.tudelft.nl/assets/uuid:10b1d4af-81dd-47c0-84f698661ea95c0d/Graduation Report Harikumaran 4118855.pdf

Hensley, R., Knupfer, S., \& Pinner, D. (2009). Electrifying cars: How three industries will evolve. The McKinsey Quarterly, 3.

IHS Global Insight (2009). Impact of the Financial and economic crisis on European industries, report prepared for the European Parliament's committee on industry. Energy and Research.

Jacobs, M., Vickery, S.K., \& Droge, C. (2007). The effects of product modularity on competitive performance: Do integration strategies mediate the relationship? International Journal of Operations \& Production Management, 27(10), 1046-1068. http://dx.doi.org/10.1108/01443570710820620

Jin, M., \& Tian, X. (2015). The research for flexible product family manufacturing based on real options. Journal of Industrial Engineering and Management, 8(1), 72-84. http://dx.doi.org/10.3926/jiem.1304

Karplus, V.J., Paltsev, S., \& Reilly, J.M. (2010). Prospects for plug-in hybrid electric vehicles in the United States and Japan: a general equilibrium analysis. Transportation Research Part A. Policy and Practice, 44(8), 620-641. http://dx.doi.org/10.1016/j.tra.2010.04.004

Keough, M. (1993). Buying your way to the top. The McKinsey Quarterly, 3, 41-62.

Khan, O., \& Creazza, A. (2009). Managing the product design - supply chain interface: towards a roadmap to the design centric business. International Journal of Physical Distribution and Logistics Management, 39(4), 301-319. http://dx.doi.org/10.1108/09600030910962258

Kline, P. (1979). Psychometrics and psychology. London: Acaderric Press.

Kraljic, P. (1983). Purchasing must become supply management. Harvard Business Review, 61(5), 109-117.

International Energy Agency (IEA) (2011). Technology Roadmap Electric and plug-in bybrid electric vehicles. http://www.iea.org/papers/2011/EV PHEV Roadmap.pdf 
Lambert, D., \& Cooper, M.C. (2000). Issues in Supply Chain Management. Industrial marketing management, 29, 65-83. http://dx.doi.org/10.1016/S0019-8501(99)00113-3

Lambert, D. (2008). Supply Chain Management: Processes, Partnerships, Performance. 3rd edition. Supply Chain Management Institute.

Lamothe, J., Hadj-Hamou, K., \& Aldanondo, M. (2006). An optimization model for selecting a product family and designing its supply chain. European Journal of Operational Research, 169, 1030-1047. http://dx.doi.org/10.1016/j.ejor.2005.02.007

Lanza, G., Stoll, J., Koelmel, A., \& Peters, S. (2012). Flexible production lines for series production of automotive electric drives. Electric Drives Production Conference (EDPC), 2012 2nd International. http://dx.doi.org/10.1109/EDPC.2012.6425088

Lee, H.L., \& Sasser, M.M. (1995). Product universality and design for supply chain management. Production Planning and Control, 6(3), 270-277. http://dx.doi.org/10.1080/09537289508930279

Liu, L., Chen, G., \& Niu, X. (2015). Game analysis of the knowledge sharing mechanism for the supply chain collaborative innovation. Journal of Industrial Engineering and Management, 8(1), 152-169. http://dx.doi.org/10.3926/jiem.1368

Luccarelli, M., Matt, D., \& Russo Spena, P. (2014). Impact of electromobility on automotive architectures. Electric Vebicle Symposium and Exhibition (EVS27), 2013 World. 1-8.

Malhotra, M.K., \& Grover, V. (1998). An assessment of survey research in POM: from constructs to theory. Journal of Operations Management, 16(4), 407-425. http://dx.doi.org/10.1016/S0272-6963(98)00021-7

McCarthy, I.P., Silvestre B.S., \& Kietzmann J.H. (2013). Understanding outsourcing contexts through information asymmetry and capability fit. Production Planning \& Control, 24(4-5), 277-283. http://dx.doi.org/10.1080/09537287.2011.648765

Milligan, G.W., \& Cooper, M.C. (1985). An examination of procedures determining the number of clusters in a data set. Psychometrica, 50,159-179. http://dx.doi.org/10.1007/BF02294245

Milligan, G.W., \& Cooper, M.C. (1987). Methodology review: Clustering methods. Applied Psychological Measurement, 11, 329-354. http://dx.doi.org/10.1177/014662168701100401

Mock, P., Hülsebusch, D., Ungethüm, J., \& Schmid, S.A. (2009). Electric vehicles - A model based assessment of future market prospects and environmental impacts. http://www.BaUsch-gall.de/Mock-paper.pdf

Müller, R. (2011). Modulare Bawweisen sind der Schlüssel. Atz production, 02/2011, S.18-20. 
Nationale Plattform Elektromobilität (NPE) (2010). Zwischenbericht der Arbeitsgruppe 1: “Antriebstechnologien und Fahrzeugintegration". Bundesministerium für Wirtschaft und Technologie.

Naylor, J.B., Naim, M.M., \& Berry, D. (1997). Leagility: interfacing the lean and agile manufacturing paradigm in the total supply chain. International Journal of Production Economics, 62, 107-118. http://dx.doi.org/10.1016/S0925-5273(98)00223-0

Nooria, H., \& Georgescua, D. (2010). Making supply chain design the rational differentiating characteristic of the OEMs. International Journal of Production Research, 46(10), 2765-2783. http://dx.doi.org/10.1080/00207540601011527

Novak, S., \& Eppinger, S. (2001). Sourcing By Design: Product Complexity and the Supply Chain. Management Science, 47(1), 189-204. http://dx.doi.org/10.1287/mnsc.47.1.189.10662

Nunnally, J.C. (1978). Psychometric Theory. New York: McGraw-Hill.

Owen, N.J., \& Gordon, R.L. (2002). Carbon to Hydrogen: Roadmaps for Passenger Cars. Ricardo Consulting report for Departments of Transport and Trade and Industry, London.

Pandremenos, J., Paralikas, J., Salonitis, K., \& Chryssolouris, G. (2009). Modularity concept for the automotive industry: a critical review. Journal of Manufacturing Science and Technology, 1, 148-152. http://dx.doi.org/10.1016/j.cirpj.2008.09.012

Pannkoke, K., \& Ernst C. (2011). Accelerated Introduction of Electric Vebicles in North West Europe. http://www.enevate.eu/ib/site/documents/media/f93291c5-6177-04c2-c30e042c474b1256.pdf/2011_EEVC_ENEVATE_template_v3_CE.pdf?Edition=en

Peck, H. (2006). Reconciling supply chain vulnerability, risk and supply chain management. International Journal of Logistics Research and Applications, 9(2), 127-142. http://dx.doi.org/10.1080/13675560600673578

Persson, M. (2006). Effects of changing a module's interface: a case study in an automotive company. International Journal of Automotive Technology and Management, 6(3), 331-345. http://dx.doi.org/10.1504/IJATM.2006.012124

Potoglou D., \& Kanaroglou, P.S. (2007). Household demand and willingness to pay for clean vehicles. Transportation Research Part D: Transport and Environment, 12(4), 264-274. http://dx.doi.org/10.1016/j.trd.2007.03.001

Preedy, V.R., \& Watson, R.R. (2009). Handbook of Disease Burdens and Quality of Life Measures. New York: Springer. 
Pullan, T.T., Bhasib, M., \& Madhuc, G. (2010). Application of concurrent engineering in manufacturing industry. International Journal of Computer Integrated Manufacturing, 23(5), 425-440.

http://dx.doi.org/10.1080/09511921003643152

Risch, F., Guenther, S., \& Franke, J. (2012). Production concepts for inductive power transfer systems for electric. Electric Drives Production Conference (EDPC), 2012 2nd International.

http://dx.doi.org/10.1109/EDPC.2012.6425129

Rungtusanatham, M., \& Forza, C., 2005. Coordinating product design, process design, and supply chain design decisions. Part A: topic motivations, performance implications, and article review process. Journal of Operations Management, 23, 257-265. http://dx.doi.org/10.1016/j.jom.2004.10.013

Schlick, T., Hertel, G., Hagemann, B., \& Maiser, E. (2011). Zukunftsfeld Elektromobilität - Chancen und Herausforderungen für den deutschen Maschinen- und Anlagenbau. Studie von Roland Berger und dem VDMA.

Sharifi, H., Ismail, H.S., \& Reid, I. (2006). Achieving agility in supply chain through simultaneous design of and design for supply chain. Journal of Manufacturing Technology Management, 17(8), 1078-1098. http://dx.doi.org/10.1108/17410380610707393

Shepherd, S., Bonsall, P., \& Harrison, J. (2012). Factors affecting future demand for electric vehicles: a model based study. Transport Policy, 20, 62-74. http://dx.doi.org/10.1016/j.tranpol.2011.12.006

Sierzchula, W., Bakker, S., Maat, K., \& van Wee, B. (2014). The influence of financial incentives and other socio-economic factors on electric vehicle adoption. Energy Policy, 68, 183-194.

http://dx.doi.org/10.1016/j.enpol.2014.01.043

Spillan, J.E., Kohn, J.W., \& McGinnis, M.A. (2010). A study of logistics strategies in small versus large U.S. manufacturing firms. Journal of Transportation Management, 21(1), 43-62.

Turton, H., \& Moura, F. (2008). Vehicle-to-grid systems for sustainable development: an integrated energy analysis. Technological Forecasting and Social Change, 75, 1091-1108.

http://dx.doi.org/10.1016/j.techfore.2007.11.013

Ulrich, K., \& Eppinger, S. (2000). Product Design and Development. Boston, MA: McGraw-Hill.

Van Hoek, R., \& Chapman, P. (2006). From tinkering around the edge to enhancing revenue growth: supply chain-new product development. Supply Chain Management: An International Journal, 11(5), 385-389. http://dx.doi.org/10.1108/13598540610682390 
Van Hoek, R., \& Chapman, P. (2007). How to move supply chain beyond cleaning up after new product development. Supply Chain Management: An International Journal, 12(4), 239-244.

http://dx.doi.org/10.1108/13598540710759745

Yadav, S.R., Mishrab, N., Kumarc, V., \& Tiwarid, M.K. (2010). A framework for designing robust supply chains considering product development issues. International Journal of Production Research, 49(20), 6065-6088. http://dx.doi.org/10.1080/00207543.2010.524258

Yu, J., \& Cooper, H. (1983). A qualitative review of research design effects on response rates to questionnaires. Journal of Marketing Research, 20(1), 36-44. http://dx.doi.org/10.2307/3151410

\section{Appendix 1. Scheme of the questionnaire used for data collection}

\section{Section 1- General information}

Q.1. Enterprise size:

- $\operatorname{micro-sized~(<10~employees)~}$

- $\quad$ small-sized (<50 employees)

- medium-sized (<250 employees)

- large-sized enterprise (> 250 employees)

Q.2. Industry field in which the enterprise operates:

Q.3. Role of the respondent to the questionnaire: 


\section{Section 2-Aspects related to the supply chain}

Q.4. Design / production / sales of electric vehicles will require us to:

- Make minor changes to the supply chain

\begin{tabular}{|l|l|l|l|l|l|}
\hline & Unimportant & $\begin{array}{c}\text { Of little } \\
\text { importance }\end{array}$ & $\begin{array}{c}\text { Moderately } \\
\text { important }\end{array}$ & Important & $\begin{array}{c}\text { Very } \\
\text { important }\end{array}$ \\
\hline $\begin{array}{l}\text { Suppliers must adapt to the demand } \\
\text { for new products }\end{array}$ & & & & & \\
\hline $\begin{array}{l}\text { Modify the existing production lines } \\
\text { for new products }\end{array}$ & & & & & \\
\hline $\begin{array}{l}\text { Modify production capacity } \\
\text { (e.g., man-hours or machine hours) }\end{array}$ & & & & & \\
\hline Internal training for workers & & & & & \\
\hline $\begin{array}{l}\text { Internal research and development } \\
\text { for new products }\end{array}$ & & & & & \\
\hline
\end{tabular}

- Make major changes to the supply chain

\begin{tabular}{|l|l|l|l|l|l|}
\hline & Unimportant & $\begin{array}{c}\text { Of little } \\
\text { importance }\end{array}$ & $\begin{array}{c}\text { Moderately } \\
\text { important }\end{array}$ & Important & $\begin{array}{c}\text { Very } \\
\text { important }\end{array}$ \\
\hline Change some suppliers & & & & & \\
\hline $\begin{array}{l}\text { Add new production lines to } \\
\text { existing lines }\end{array}$ & & & & & \\
\hline Partial outsourcing & & & & & \\
\hline Recruitment of new skilled workers & & & & & \\
\hline $\begin{array}{l}\text { Establish relationships with new } \\
\text { customers }\end{array}$ & & & & & \\
\hline
\end{tabular}

- Make radical and total changes to the supply chain

\begin{tabular}{|l|l|l|l|l|l|}
\hline & Unimportant & $\begin{array}{c}\text { Of little } \\
\text { importance }\end{array}$ & $\begin{array}{c}\text { Moderately } \\
\text { important }\end{array}$ & Important & $\begin{array}{c}\text { Very } \\
\text { important }\end{array}$ \\
\hline Totally new suppliers & & & & & \\
\hline Create new production facilities & & & & & \\
\hline Total outsourcing & & & & & \\
\hline Transition to an agile supply chain & & & & & \\
\hline $\begin{array}{l}\text { External research and development } \\
\text { for new products }\end{array}$ & & & & & \\
\hline $\begin{array}{l}\text { Considering collaboration } \\
\text { agreements such as joint ventures }\end{array}$ & & & & & \\
\hline
\end{tabular}


Q.5. Please indicate the attention that your enterprise pays to these key supply chain processes:

\begin{tabular}{|l|l|l|l|l|l|}
\hline Unimportant & $\begin{array}{c}\text { Of little } \\
\text { importance }\end{array}$ & $\begin{array}{c}\text { Moderately } \\
\text { important }\end{array}$ & \multicolumn{1}{|c|}{ Important } & $\begin{array}{c}\text { Very } \\
\text { important }\end{array}$ \\
\hline Customer relationship management & & & & & \\
\hline Demand management style & & & & & \\
\hline Manufacturing flow management & & & & & \\
\hline Order fulfilment & & & & & \\
\hline Outsourcing/partnerships & & & & & \\
\hline Performance measurement & & & & \\
\hline $\begin{array}{l}\text { Product development and } \\
\text { commercialisation }\end{array}$ & & & & & \\
\hline Returns management & & & & & \\
\hline Supplier relationship management & & & & & \\
\hline Warehousing management & & & & & \\
\hline
\end{tabular}

\section{Section 3-About the electric vehicles market}

Q.6. In which sort of electric vehicles / field is your enterprise investing more (e.g., research \& development, facilities, or resources)?

- $\square$ Hybrid

- $\square$ Plug-in hybrid

- $\square$ Full electric

- $\square$ Other (specify)

Q.7. Which of these body styles are car manufacturers mainly developing for electric vehicles?

- $\square$ city car

- $\square$ sedan

- $\square$ station wagon

- $\square$ multi-purpose vehicle

- $\square$ suv

- $\square$ coupe/roadster 
Q.8. The market creates an environment that encourages innovation towards electric vehicles:

- $\square$ Strongly agree

- $\square$ Agree

- $\square$ Neutral

- $\square$ Disagree

- $\square$ Strongly disagree

Q.9. Please indicate the degree of importance that you (or your enterprise) attribute to the market for electric vehicles:

- $\square$ Very important

- $\square$ Important

- $\square$ Moderately important

- $\square$ Of Little importance

- $\square$ Unimportant

Q.10. When will the market for electric vehicles be predominant with respect to conventional vehicles?

- $\square 2020$

- $\square 2030$

- $\square 2040$

- $\square 2050$

- $\square$ Never

Q.11. How much more does an electric vehicle cost than an equivalent conventional vehicle?

\begin{tabular}{|l|l|l|l|l|l|}
\hline Economic aspects & Less than 2,000, & $2,000,-4,000$, & $4,000,-6,000$, & $6,000,-10,000$, & $\begin{array}{c}\text { More than } \\
10,000,\end{array}$ \\
\hline Hybrid & & & & & \\
\hline Plug-in hybrid & & & & & \\
\hline Full electric & & & & & \\
\hline
\end{tabular}




\section{Section $4-$ Critical aspects}

Q.12. Please indicate the degree of criticality you assign to these technical aspects in the design of an electric vehicle:

\begin{tabular}{|l|l|l|l|l|l|}
\hline & $\begin{array}{c}\text { Very } \\
\text { uncritical }\end{array}$ & Uncritical & $\begin{array}{c}\text { Moderately } \\
\text { critical }\end{array}$ & Critical & Very critical \\
\hline Battery packs & & & & & \\
\hline Safety in the case of collision & & & & & \\
\hline Acceleration & & & & & \\
\hline Top speed & & & & & \\
\hline Consumption (km/litre) & & & & & \\
\hline Driving range (km with a full tank) & & & & & \\
\hline Size of the passenger compartment & & & & & \\
\hline Hi-Tech appearance & & & & & \\
\hline Flywheel / transmission & & & & & \\
\hline Coefficient of aerodynamic drag (cx) & & & & & \\
\hline Body frame & & & & & \\
\hline
\end{tabular}

\section{Section 5 - About incentives}

Q. 13. Incentives greatly facilitate the diffusion of electric vehicles:

- $\square$ Strongly agree

- $\square$ Agree

- $\square$ Neutral

- $\square$ Disagree

- $\square$ Strongly disagree

Q. 14. Please indicate the degree of effectiveness of the following incentives:

\begin{tabular}{|l|l|l|l|l|l|}
\hline & $\begin{array}{c}\text { Very } \\
\text { ineffective }\end{array}$ & Ineffective & $\begin{array}{c}\text { Somewhat } \\
\text { effective }\end{array}$ & Effective & $\begin{array}{c}\text { Very } \\
\text { effective }\end{array}$ \\
\hline Purchase price incentives & & & & & \\
\hline Road tax incentives & & & & & \\
\hline Car insurance incentives & & & & & \\
\hline Rebates on fuel prices (e.g., $1 € / 1)$ & & & & & \\
\hline Tax-holidays & & & & & \\
\hline
\end{tabular}




\section{Appendix 2. Additional statistical analysis of factors}

\begin{tabular}{|c|c|c|c|c|c|c|c|c|c|c|c|c|c|c|c|c|c|}
\hline & & 1 & 2 & 3 & 4 & 5 & 6 & 7 & 8 & 9 & 10 & 11 & 12 & 13 & 14 & 15 & 16 \\
\hline \multirow{3}{*}{ item 1} & Correlation coefficient & 1 & $.683 * *$ & $.576^{* *}$ & $.438^{* *}$ & $.397 * *$ & .138 & .142 & .188 & .143 & .084 & .071 & .140 & .102 & .181 & .010 & .092 \\
\hline & Sig. (2-code) & & .000 & .000 & .000 & .000 & .202 & .191 & .080 & .187 & .440 & .516 & .196 & .347 & .094 & .924 & .399 \\
\hline & $\mathrm{N}$ & 113 & 113 & 113 & 113 & 113 & 113 & 113 & 113 & 113 & 113 & 113 & 113 & 113 & 113 & 113 & 113 \\
\hline \multirow{3}{*}{ item 2} & Correlation coefficient & $.683^{* *}$ & 1 & $.787 * *$ & $.697 * *$ & $.474^{* *}$ & .150 & .030 & .060 & .111 & .201 & -.037 & .086 & -.109 & -.101 & .103 & .152 \\
\hline & Sig. (2-code) & .000 & & .000 & .000 & .000 & .167 & .780 & .581 & .305 & .062 & .731 & .428 & .314 & .352 & .341 & .161 \\
\hline & $\mathrm{N}$ & 113 & 113 & 113 & 113 & 113 & 113 & 113 & 113 & 113 & 113 & 113 & 113 & 113 & 113 & 113 & 113 \\
\hline \multirow{3}{*}{ item 3} & Correlation coefficient & $.576^{* *}$ & $.787 * *$ & 1 & $.682 * *$ & $.400^{* *}$ & .091 & .055 & .096 & .106 & .023 & -.042 & .102 & .107 & -.128 & .133 & .143 \\
\hline & Sig. (2-code) & .000 & .000 & & .000 & .000 & .401 & .615 & .377 & .329 & .835 & .699 & .347 & .323 & .236 & .220 & .185 \\
\hline & $\mathrm{N}$ & 113 & 113 & 113 & 113 & 113 & 113 & 113 & 113 & 113 & 113 & 113 & 113 & 113 & 113 & 113 & 113 \\
\hline \multirow{3}{*}{ item 4} & Correlation coefficient & $.438^{* *}$ & $.697 * *$ & $.682^{* *}$ & 1 & $.390^{* *}$ & .177 & .084 & .106 & .142 & .073 & -.030 & -.184 & .192 & .110 & -.022 & .065 \\
\hline & Sig. (2-code) & .000 & .000 & .000 & & .000 & .102 & .441 & .327 & .191 & .499 & .784 & .089 & .075 & .309 & .841 & .548 \\
\hline & $\mathrm{N}$ & 113 & 113 & 113 & 113 & 113 & 113 & 113 & 113 & 113 & 113 & 113 & 113 & 113 & 113 & 113 & 113 \\
\hline \multirow{3}{*}{ item 5} & Correlation coefficient & $.397^{* *}$ & $.474 * *$ & $.400^{* *}$ & $.390 * *$ & 1 & .086 & .104 & .178 & .098 & .153 & .073 & .177 & .180 & .144 & .064 & .078 \\
\hline & Sig. (2-code) & .000 & .000 & .000 & .000 & & .429 & .339 & .099 & .368 & .157 & .500 & .100 & .096 & .183 & .559 & .470 \\
\hline & $\mathrm{N}$ & 113 & 113 & 113 & 113 & 113 & 113 & 113 & 113 & 113 & 113 & 113 & 113 & 113 & 113 & 113 & 113 \\
\hline \multirow{3}{*}{ item 1} & Correlation coefficient & .138 & .150 & .091 & .177 & .086 & 1 & $.636^{* *}$ & $.699 * *$ & $.548^{* *}$ & $.605^{* *}$ & .172 & .159 & .128 & .153 & .054 & .117 \\
\hline & Sig. (2-code) & .202 & .167 & .401 & .102 & .429 & & .000 & .000 & .000 & .000 & .112 & .140 & .237 & .158 & .620 & .281 \\
\hline & $\mathrm{N}$ & 113 & 113 & 113 & 113 & 113 & 113 & 113 & 113 & 113 & 113 & 113 & 113 & 113 & 113 & 113 & 113 \\
\hline \multirow{3}{*}{ item 2} & Correlation coeffic & .142 & .030 & .055 & .084 & .104 & $.636^{* *}$ & 1 & $.919^{* *}$ & $.690 * *$ & $.699 * *$ & .106 & .003 & .194 & .198 & .160 & -.046 \\
\hline & Sig. (2-code) & .191 & .780 & .615 & .441 & .339 & .000 & & .000 & .000 & .000 & .329 & .976 & .072 & .066 & .138 & .671 \\
\hline & $\mathrm{N}$ & 113 & 113 & 113 & 113 & 113 & 113 & 113 & 113 & 113 & 113 & 113 & 113 & 113 & 113 & 113 & 113 \\
\hline \multirow{3}{*}{ item 3} & Correlation coefficient & .188 & .060 & .096 & .106 & .178 & $.699 * *$ & $.919 * *$ & 1 & $.785^{* *}$ & $.698^{* *}$ & .142 & .143 & .032 & .101 & .198 & .210 \\
\hline & Sig. (2-code) & .080 & .581 & .377 & .327 & .099 & .000 & .000 & & .000 & .000 & .188 & .187 & .766 & .350 & .066 & .051 \\
\hline & $\mathrm{N}$ & 113 & 113 & 113 & 113 & 113 & 113 & 113 & 113 & 113 & 113 & 113 & 113 & 113 & 113 & 113 & 113 \\
\hline \multirow{3}{*}{ item 4} & Correlation coefficient & .143 & .111 & .106 & .142 & .098 & $.548^{* *}$ & $.690 * *$ & $.785^{* *}$ & 1 & $.749^{* *}$ & .098 & .194 & .159 & .096 & .165 & .159 \\
\hline & Sig. (2-code) & .187 & .305 & .329 & .191 & .368 & .000 & .000 & .000 & & .000 & .369 & .072 & .141 & .379 & .128 & .141 \\
\hline & $\mathrm{N}$ & 113 & 113 & 113 & 113 & 113 & 113 & 113 & 113 & 113 & 113 & 113 & 113 & 113 & 113 & 113 & 113 \\
\hline \multirow{3}{*}{ item 5} & Correlation coefficient & .084 & .201 & .023 & .073 & .153 & $.605^{* *}$ & $.699 * *$ & $.698^{* *}$ & $.749 * *$ & 1 & .054 & .098 & .017 & .023 & .055 & .034 \\
\hline & Sig. (2-code) & .440 & .062 & .835 & .499 & .157 & .000 & .000 & .000 & .000 & & .621 & .369 & .878 & .831 & .612 & .755 \\
\hline & $\mathrm{N}$ & 113 & 113 & 113 & 113 & 113 & 113 & 113 & 113 & 113 & 113 & 113 & 113 & 113 & 113 & 113 & 113 \\
\hline \multirow{3}{*}{ item 1} & Correlation coefficient & .071 & -.037 & -.042 & -.030 & .073 & .172 & .106 & .142 & .098 & .054 & 1 & $.860^{* *}$ & $.588^{* *}$ & $.759 * *$ & $.491 * *$ & $.530 * *$ \\
\hline & Sig. (2-code) & .516 & .731 & .699 & .784 & .500 & .112 & .329 & .188 & .369 & .621 & & .000 & .000 & .000 & .000 & .000 \\
\hline & $\mathrm{N}$ & 113 & 113 & 113 & 113 & 113 & 113 & 113 & 113 & 113 & 113 & 113 & 113 & 113 & 113 & 113 & 113 \\
\hline \multirow{3}{*}{ item 2} & Correlation coefficient & .140 & .086 & .102 & -.184 & .177 & .159 & .003 & .143 & .194 & .098 & $.860^{* *}$ & 1 & $.532 * *$ & $.647 * *$ & $.443^{* *}$ & $.549 * *$ \\
\hline & Sig. (2-code) & .196 & .428 & .347 & .089 & .100 & .140 & .976 & .187 & .072 & .369 & .000 & & .000 & .000 & .000 & .000 \\
\hline & $\mathrm{N}$ & 113 & 113 & 113 & 113 & 113 & 113 & 113 & 113 & 113 & 113 & 113 & 113 & 113 & 113 & 113 & 113 \\
\hline \multirow{3}{*}{ item 3} & Correlation coefficient & .102 & -.109 & .107 & .192 & .180 & .128 & .194 & .032 & .159 & .017 & $.588^{* *}$ & $.532^{* *}$ & 1 & $.512^{* *}$ & $.564^{* *}$ & $.671 * *$ \\
\hline & Sig. (2-code) & .347 & .314 & .323 & .075 & .096 & .237 & .072 & .766 & .141 & .878 & .000 & .000 & & .000 & .000 & .000 \\
\hline & $\mathrm{N}$ & 113 & 113 & 113 & 113 & 113 & 113 & 113 & 113 & 113 & 113 & 113 & 113 & 113 & 113 & 113 & 113 \\
\hline \multirow{3}{*}{ item 4} & Correlation coefficient & .181 & -.101 & -.128 & .110 & .144 & .153 & .198 & .101 & .096 & .023 & $.759 * *$ & $.647 * *$ & $.512 * *$ & 1 & $.735^{* *}$ & $.487 * *$ \\
\hline & Sig. (2-code) & .094 & .352 & .236 & .309 & .183 & .158 & .066 & .350 & .379 & .831 & .000 & .000 & .000 & & .000 & .000 \\
\hline & $\mathrm{N}$ & 113 & 113 & 113 & 113 & 113 & 113 & 113 & 113 & 113 & 113 & 113 & 113 & 113 & 113 & 113 & 113 \\
\hline \multirow{3}{*}{ item 5} & Correlation coefficient & .010 & .103 & .133 & -.022 & .064 & .054 & .160 & .198 & .165 & .055 & $.491 * *$ & $.443^{* *}$ & $.564 * *$ & $.735^{* *}$ & 1 & $.593 * *$ \\
\hline & Sig. (2-code) & .924 & .341 & .220 & .841 & .559 & .620 & .138 & .066 & .128 & .612 & .000 & .000 & .000 & .000 & & .000 \\
\hline & $\mathrm{N}$ & 113 & 113 & 113 & 113 & 113 & 113 & 113 & 113 & 113 & 113 & 113 & 113 & 113 & 113 & 113 & 113 \\
\hline \multirow{3}{*}{ item 6} & Correlation coefficient & -.092 & .152 & .143 & .065 & .078 & .117 & -.046 & .210 & .159 & .034 & $.530^{* *}$ & $.549^{* *}$ & $.671^{* *}$ & $.487 * *$ & $.593^{* *}$ & 1 \\
\hline & Sig. (2-code) & .399 & .161 & .185 & .548 & .470 & .281 & .671 & .051 & .141 & .755 & .000 & .000 & .000 & .000 & .000 & \\
\hline & $\mathrm{N}$ & 113 & 113 & 113 & 113 & 113 & 113 & 113 & 113 & 113 & 113 & 113 & 113 & 113 & 113 & 113 & 113 \\
\hline
\end{tabular}

Journal of Industrial Engineering and Management, 2016 (www.jiem.org)

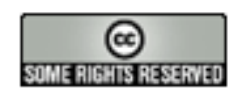

Article's contents are provided on an Attribution-Non Commercial 3.0 Creative commons license. Readers are allowed to copy, distribute and communicate article's contents, provided the author's and Journal of Industrial Engineering and Management's names are included. It must not be used for commercial purposes. To see the complete license contents, please visit http://creativecommons.org/licenses/by-nc/3.0/. 